\title{
Marine biodiversity offsetting: An analysis of the emergence of an environmental governance system in California
}

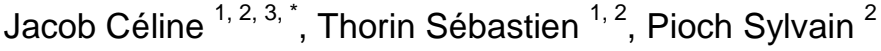 \\ ${ }^{1}$ CREOCEAN, Les Belvédères, Bâtiment B, 128, avenue de Fès, 34080 Montpellier, France \\ ${ }^{2}$ CEFE UMR 5175, CNRS - Université de Montpellier - Université Paul-Valéry Montpellier - EPHE - \\ Université Paul-Valéry Montpellier, Route de Mende 34199 Montpellier Cedex 5, France \\ ${ }^{3}$ Ifremer, Univ Brest, CNRS, UMR 6308, AMURE, Unité d'Economie Maritime, IUEM, 29280 Plouzané, \\ France \\ *Corresponding author : Céline Jacob, email address : celine.jacob@ifremer.fr \\ thorin@creocean.fr ; sylvain.pioch@gmail.com
}

\begin{abstract}
:
Most research studies related to biodiversity offsetting have focused on governance systems already in place in the terrestrial realm - these studies tend to rely on an approach of organizational economics, in particular in relation to mitigation banking schemes. In this study, emerging marine offsetting governance systems has been analyzed using the Actor-Network Theory (ANT) with the aim of highlighting the key elements that enable the emergence of marine offsetting tools. The ANT framework has been applied to four case studies in California using data collected in a field study that consisted of interviewing 30 stakeholders working closely with the issue of marine offsetting. Employing ANT allowed to ascertain the role of commonly studied elements such as impacted ecosystems, sizing methodologies and ecological engineering techniques. Further, it highlighted the key role of other critical factors, such as 'skilled intermediaries', who succeed in overcoming uncertainties generated by the use of new tools and contribute to leading other stakeholders towards the goal: the offset instrument. These mediators call upon effective translation processes to put forward new arguments: a change in spatial and temporal scales and adaptive solutions. The findings point to a line of approach that encourages reconfiguring environmental governance systems that could benefit from feedbacks from Integrated Coastal Zone Management (ICZM) and Marine Spatial Planning (MSP) processes, in order to facilitate the development of marine offset schemes.
\end{abstract}

\section{Highlights}

Key enabling processes for the implementation of marine offset schemes are identified. The ActorNetwork theory is used to study the offset governance systems. Reconfiguration of stakeholders and changes in scales are crucial elements.

Keywords : Governance, Biodiversity offset, Marine ecosystems, Actor-Network theory, California 
To date, most scientific literature examining biodiversity offsetting schemes has focused on systems developed to offset authorized impacts in terrestrial ecosystems. Currently, three types of scheme are mainly used in terrestrial contexts:

- Permittee-responsible mitigation (PRM): The permittee causing the authorized impact implements (itself or through an authorized agent or contractor) offset measures; the permittee retains full responsibility.

- Mitigation banking: An operator, which is neither the permittee nor the regulator, undertakes ecological actions in anticipation of future development projects with an ecological impact. This operator then translates these actions into value through the sale of credits to developers that need to compensate for impacts on the same habitats or species in the same defined area as the actions undertaken by the bank.

- In-lieu fee (ILF) mitigation: Financial funds are collected from one or several developers causing authorized impacts in order to implement offset measures. These are managed by a public-sector stakeholder or a non-governmental organization (NGO).

Research to date has particularly focused on mitigation banking, which integrates, within an explicit framework, criteria such as equivalence calculation, exchange rules, and legal and financial guarantees [1]. Mitigation banking schemes have benefited from being tested in practice; the first was implemented in the early 1990s in the United States. However, in a marine context, offsetting systems are currently in their very early stages of development (for example, the state of Florida has 3 marine mitigation banks compared to around 90 terrestrial mitigation banks). As of yet, few studies have been dedicated to marine offsetting, so this research topic anticipates a future field.

In this study, rather than investigating governance systems already in place (mainly designed for the terrestrial context), emerging governance systems currently in development were analyzed. With this aim, marine offsetting in California was addressed using the Actor-Network Theory (ANT). Like the neoinstitutional economics approaches commonly used to study organizational modes related to mitigation banking $[2,3,4]$, the sociological framework of ANT stems from the organization theory. The ANT is a sociological approach that was developed in the 1980s by, among others, M. Callon, B. Latour and M. Akrich to deepen the understanding of processes in science production and, in particular, the elaboration of scientific facts in laboratories [55]. For instance, this has been applied to investigate the construction of credibility for new evaluations and assessments (environmental capital, ecological footprinting, and green infrastructure) [8]. This approach is of interest for marine offset as it enables the study of science and technology 'in the making' [5], and marine offsetting is still in its pioneering and innovative phase.

California was chosen as the study area since this state is part of a nation with the largest marine Exclusive Economic Zone in the world $\left(11,350\right.$ million $\left.\mathrm{km}^{2}\right)$. California's marine regulations are also some of the most far-reaching. It was one of the coastal states most deeply involved in defining the programs in the Coastal 
Zone Management Act (1972), a reference text in global policy on coastal zone management. California was the second state to sign this act [6].

This article studies the relations between the elements of the socio-ecological system to help identifying the different strategies developed by the stakeholders and the key enabling processes for the implementation of marine offset schemes. In section 2, the theoretical framework is detailed. The stakeholders who were interviewed, the documents that were reviewed, and the items related to the ANT concepts around which the analysis is organized are outlined in section 3. Section 4 displays the four case studies encountered in California and the information needed for the ANT application. For each case study, the different elements of ANT explaining the emergence of marine offsetting schemes are discussed in section 5 . The last section describes how the reconfiguration of environmental governance constitutes a crucial element in the design of marine offsetting schemes.

\section{Theoretical framework}

Generally, the creation of knowledge (or innovation) is presented as linear, transferred from the originator to the receiver. In contrast, Callon, Latour and Akrich proposed the Actor-Network Theory, which argues that information is received not only according to its internal merits ('the facts') but also according to the receivers' strategies and aims for using it [55]. ANT thus emphasizes the importance of translating information in a way that is pertinent to receivers' concerns in order to recruit them into actions. This process takes place in a network of stakeholders.

Organizational dynamism relies on this capacity to translate information. Thus, it is essential to establish what ANT terms an 'obligatory passage point', shared by a network of stakeholders [5, 7], through which other stakeholders must pass in order to reach their goal. ANT does not create a division between words and things or between human and non-human elements: all participate in a collective action and are referred to as 'actants'.

When analyzing the emergence of new tools or 'knowledge' according to ANT, their qualities are considered as just one element in a more complex picture; it is equally crucial to understand 'how knowledge claims become incorporated into the actions, values, and projects of others' [8]. The role of external, social, and economic factors is decisive in stabilizing connections between knowledge and action. As mentioned by Cowell and Lennon [8], entrenching the use of a methodology depends on 'a complex and sometimes precarious assemblage of knowledge content, metaphor, policy resources, and institutional setting'. This assemblage can affect the limits of the relevance of what are effectively social abstractions (i.e. evaluations) as bearers of values; key stakeholders normally have to agree on these limits [9]. A new methodology or tool, also called a 'politico-technical artefact' [10], must 'combine irresistible forms of knowledge with political legitimacy' in order to make it less subject to negotiation [11].

Thus, in ANT it is crucial to identify the 'positive modalities' (consolidating) and 'negative modalities' (contesting) in a new tool or 'knowledge'. The former are related to arguments that move the debate away from the contestable conditions in which knowledge was produced so that they can be used to underlie actions. The latter consist of arguments that focus on the conditions in which knowledge was produced, questioning the methods, data or assumptions. In addition to these key elements within ANT, Cowell and Lennon [8] highlight the important role of 'skilled intermediaries' or 'policy entrepreneurs'. These intermediaries have the ability to forge links between key stakeholders and are able to explain the potential value of the tool to others and address any negative modalities. These facilitators are crucial, as the adoption of a tool must 'driv[e] forward particular conceptions of sustainability across a range of 
governmental sectors, each with their own forms of knowledge and expertise, normative criteria, and policy territories' [12 In: 10].

In ANT, ecosystems are 'actants' in the same way as stakeholders. Indeed, as mentioned by [13], 'a theme that runs through geographical analysis of environmental governance [...] is how the biophysical properties of natural resources and ecological systems impinge on and shape the organizational and institutional systems through which they are governed'. Thus, governance schemes are fundamentally linked to particular ecosystems, and this relationship affects the way that governments seek to manage economic development in their territories [14]. Indeed, different levels of uncertainty prevail in different ecological systems (in terms of scientific knowledge, restoration techniques and methodologies used to assess offset needs). As demonstrated by Jacob et al. [15], an ecological impact assessment relies strongly on the studied ecosystem and ecological restoration techniques also vary greatly according to the ecosystem. So a thorough analysis requires taking into account all the different elements of an ecological system, including the various aspects of human entities and their articulations.

\section{Materials and methods}

An experimental approach based on interviews with various stakeholders involved in marine offsetting in California was used to study the different governance systems implemented in this field and the resulting offsetting instruments. The field study was conducted over a month and a half in 2015 between San Diego and San Francisco in the state of California in the United States. 30 stakeholders were interviewed working in the field of marine offsetting in face-to-face, semi-structured interviews. These 30 persons were selected either because of their past experience with one of the case studies or because of their strong expertise in Californian mitigation. The interviews were carried out with public-sector stakeholders 6 representatives from federal agencies and 9 representatives from state agencies), private stakeholders (3 environmental consultants and 5 private developers) and scientists ( 7 researchers). The scientists played a role in the monitoring of one or several case studies, either during impact assessment or restoration processes.

Key documents for examination of the case studies were identified thanks to the interviews, providing technical elements necessary to inform the ANT framework. The interviews enabled to get a narrative around each example, but also to understand the position of each stakeholder and the stakes of the different agencies that do not appear in the reports. The four case studies analyzed here were the result of crossreferencing data gathered during the enquiries. They represent the examples most quoted by the interviewees. This choice was also determined by the availability of information that allowed the selected analytical framework (ANT) to be applied correctly.

The stakeholders and their roles in marine offsetting are briefly described in Appendix 1. Each agency or organization is considered as a human 'actant' whose objectives were those described by their mandates and responsibilities as defined in relevant regulations. A given federal agency, which may appear as a monolithic actor from the outside, in fact has multiple and intersecting interests as mentioned by Robertson [16] in his essay on environmental governance resulting from his experience within the Environmental Protection Agency (EPA). Although acknowledging this duality, in this analysis each agency is seen as a unified entity. Thus, the roles and motivations of individual agents within these organizations were not explored. Indeed, such an analysis would have been too complex to be conducted on four case studies in a limited time.

In addition, various documents were reviewed such as Environmental Impact Assessments (EIAs), authorization permits, monitoring reports and recommendation documents, as well as related regulations 
(see Appendix 2). The three major sizing methodologies used for offset measures and mentioned during interviews are detailed in Appendix 3.

The different information gathered for each case study presented in the following section were then organized around five items related to the ANT concepts (in brackets): (i) the natural elements that were impacted and the pressures that triggered this impact (non-human actants), (ii) the different stakeholders who had a role in the development of the offset instrument (human actants), (iii) the status of the impacted elements in view of the regulation, the sizing methodologies and the restoration techniques used for the offset, the timeframe and the localization of the project (potential modalities), (iv) the discussions and negotiations between the different stakeholders (translation elements) (v) the binding instrument (obligatory passage point).

\section{Presentation of the collected data: the four case studies}

\subsection{Case study 1: California Eelgrass Mitigation Policy}

In 1991, the National Marine Fisheries Service (NMFS), the US Fish and Wildlife Service (USFWS) and the California Department of Fish and Wildlife (CDFW) drafted the Southern California Eelgrass Mitigation Policy, containing guidelines related to mitigating impacts on eelgrass. This policy concerned only southern California and was relatively easy to develop and enforce. Later, it was decided to devise a new document that would apply to the entire state; this expansion of the policy is the case study analyzed here.

The fact that eelgrass delivers numerous scientifically proven ecosystem services (e.g. in regulating coastal erosion, oxygenating seawater, producing organic matter and nutrients, and providing nursery, spawning and refuge zones) was a strong argument for developing environmental policies in relation to this species. Indeed, its importance is acknowledged in a number of regulations, such as the Magnuson-Stevens Fishery Conservation and Management Act, which designates eelgrass as an Essential Fish Habitat and a Habitat Area of Particular Concern, as well as the Clean Water Act (Section 404), which considers shallow waters vegetated with eelgrass as Special Aquatic Sites. This species unites the environmental objectives of several environmental agencies - the USFWS, NMFS, EPA and US Army Corps of Engineers (USACE) - under one protection and management goal. The guidelines in the NMFS 'No Net Loss' eelgrass policy comply with EPA and USACE regulatory requirements, but also provide more specific recommendations on avoiding and reducing impacts on eelgrass and implementing monitoring, evaluation and offsetting for losses [17]. The NMFS West Coast Regional Office played a major role in designing the new statewide guidelines, but supplementary reviews were undertaken at the federal level (internally) and by other agencies involved, including the California Coastal Commission. Following five years of collaborative work, the California Eelgrass Mitigation Policy was released in 2014 in a more scientific format (monitoring requirements are more complex).

These new guidelines outline different options for offsetting eelgrass losses: conservation management plans, in-kind offsetting (the preferred option), mitigation banking, in-lieu fee programs, and out-of-kind offsetting. To ensure that no losses could be attributed to a delay in the implementation of offsets, the guidelines stipulate a surface ratio of 1.2:11, calculated using a similar methodology as that used in Habitat Equivalency Analysis (HEA) as described in The Five-Step Wetland Mitigation Ratio Calculator [18]. This

\footnotetext{
${ }^{1}$ Ratios are expressed as 'offset zone:impacted zone'.
} 
ratio assumes that restored eelgrass attains equivalent habitat functioning within three years, an average rate based on feedback from 47 transplantation projects carried out over 25 years in southern California $[19,20,21]$. This ratio can be adapted according to the area in question. Every five years, the guidelines can be reevaluated according to the data gathered.

NMFS uses the recommendations in these guidelines to comment on actions subject to the National Environmental Policy Act (NEPA). According to the Magnuson-Stevens Act, federal agencies must consult with NMFS before authorizing any actions funded or undertaken by that agency that potentially impact an Essential Fish Habitat. NFMS comments are forwarded to the responsible agency, which can either take up the recommendations or explain why they will not be followed. Under the Fish and Wildlife Coordination Act (FWCA), the NMFS recommendations must be taken up; however, the responsible agency has final accountability for the protection measures adopted. Consequently, these recommendations should not be interpreted as binding for public authorities. Nonetheless, USACE refers to these guidelines in the permits it issues, and the California Coastal Commission often requires the coastal development permits it delivers to be compliant with them.

\subsection{Case study 2: San Onofre Nuclear Generating Station - permittee-responsible mitigation}

When the California Coastal Commission was created in 1972 by voter initiative following residents' concern about defending public access to the sea, it had to deal with a highly controversial topic: the creation of two new nuclear power stations on the coast. After refusing the construction of Units 2 and 3 of the San Onofre Nuclear Generating Station (SONGS) in 1973, the Coastal Commission authorized them in 1974 on the condition that an independent committee be set up - the Marine Committee Review (MCR) - to lead a thorough review of the impacts of commissioning these units and to define, if necessary, offsets for environmental impacts. The resulting committee was made up of three members: one appointed by the Coastal Commission (representing the state's interests), one appointed by the electric utility Southern California Edison (representing the interests of the permittee), and the third appointed by the NGO Friends of the Earth ${ }^{2}$ (representing the interests of opponents of the project). In addition, an independent researcher was specifically appointed to conduct an analysis of the proposed offset measures. Thus the committee embodied two opposing visions: that of the scientific experts appointed by the electric utility (SCE), who advocated for the power plant's lack of impacts, and that of environmentalist organizations, which feared critical impacts. The units were commissioned in 1983 and 1984, and the MRC issued its final conclusions concerning their ecological impact to the Coastal Commission in 1989. Its report concluded that there were significant negative effects on macroalgal beds in the vicinity of cooling water outfalls from the two units ${ }^{3}$. The discharge plume was found to trigger a substantial reduction in (a) the abundance and density of macroalgae, (b) the abundance and biomass of most of the kelp-bed fish species studied by the MCR, and (c) the abundance of large invertebrates inhabiting the kelp reef. The adult fish populations in the Southern Californian Bight as well as the local midwater fish populations were also impacted by the entrainment and impingement of larvae through the site's water intake. Other agencies (NMFS, USFWS and CDFW) were consulted to help define offset measures, but they were not required to approve the permit related to offsets.

Following the MCR's final report on the site's detrimental environmental effects, the SONGS permit was amended in 1991 and again in 1997 [22] in order to integrate the following mitigation measures:

\footnotetext{
${ }^{2}$ Friends of the Earth is an NGO working on environmental and human rights issues. It was created in 1969 and operates in 76 countries.

${ }^{3}$ http://marinemitigation.msi.ucsb.edu/
} 
- The creation or restoration of 61 ha of wetlands in southern California to compensate for the fish loss in the bight.

- The construction of an artificial reef of a size sufficient to ensure the development of 61 ha of giant kelp and its associated communities, and the creation of a fund for a fish hatchery program as compensatory mitigation for adverse impacts to the kelp community.

- The installation of behavioral barrier devices in the plant's seawater intake systems to reduce future losses of local midwater fish.

- The provision of necessary funds for technical oversight, monitoring, and performance assessment of the mitigation projects, undertaken by independent scientists.

As noted in the last point, the amended permit required monitoring from independent scientists during the offsetting phase. It specified that performance standards must be attained within 10 years and would be considered successful if standards were maintained for 3 consecutive years. These performance standards were also required to be met during the full period of operation of Units 2 and 3, including decommissioning, and until the complete elimination of any discharge.

\section{a. Project 1: Artificial reef (in-kind offset)}

To offset the impact of SONGS, the MRC recommended the implementation of an artificial reef with a surface area 1.5 times larger than the 80 ha of impacted area to take into account uncertainties [23]. However, the Coastal Commission approved the creation of a smaller artificial reef of 61 ha on the condition that an experimental reef be created beforehand to reduce these uncertainties. Based on a literature review of the historical distribution of kelp on artificial reefs in southern California and on a study of the most suitable substrates [24], an experimental reef project including eight different alternatives was designed and immersed off the coast of San Clemente in 1999. After five years of monitoring, these alternatives proved to be very similar in terms of attaining performance standards. The permittee (the electric utility) chose the version with the minimal required size (61 ha) in light of the results of the experimental phase. This became the Wheeler North Reef, which was submerged in 2008.

In the last available monitoring report (from 2015: 25), the reef functioning was considered as satisfactory similar or better than a natural reef in the region - but it has never met the standard related to fish biomass production, one of the four 'absolute standards' (the others being (1) $90 \%$ of hard substrate available for biocenosis colonization, (2) sustainability of 150 acres of kelp, and (3) absence of undesirable or invasive species). Thus the reef has never obtained offset credits as it has never met all four absolute standards in one year.

The MCR has explained these shortfalls in performance by the limited size of the reef and has recommended adding new units to increase the surface area of the offset.

\section{b. Project 2 : coastal wetlands restoration (out-of-kind offset)}

In accordance with the SONGS permit requirement to restore wetlands to compensate for impacts, in 1992, the MCR selected San Dieguito Lagoon to be restored. The project stipulated that 14 ha be granted for the maintenance of the lagoon inlet in open conditions and 47 ha be created or restored. This sizing was the result of the MCR's observation that, depending on the site and the program, wetlands restoration provides the equivalent or double the ecological value produced by an artificial reef (in terms of surface area). 
The wetlands restoration project began in 2006 and was completed in 2011. To obtain mitigation credits for a given year, a restoration project must satisfy all the absolute standards and as many relative standards as the less functional reference site.

To date, San Dieguito has never met the absolute standard related to habitat due to insufficient plant cover (the other four absolute standards have been met: these are related to topography, tidal prism, plant reproductive success, and exotic species) [26]. Neither did the restoration project attain the relative standards in three out of four years, nor the standards relative to biological communities in year 4 . Despite encouraging signs regarding the capacity of this lagoon to provide a habitat and support the food web, the project has never received offset credits.

At SONGS itself, Units 2 and 3 were definitively stopped in January 2012 following technical issues, and in June 2013, they were decommissioned permanently. However, the cooling of the units will take several years before dismantling can be carried out. Thus, impacts are still occurring in the marine environment, although they will decrease with the abatement of water intake and discharge.

The SONGS mitigation project called upon unprecedented environmental management that could not rely on existing feedback and thus had to draw upon an innovative approach with substantial monitoring resources (impact evaluation was also conducted during the operating phase of Units 2 and 3 of the plant).

\subsection{Case study 3: Port of Los Angeles - umbrella mitigation bank}

The Port of Los Angeles (POLA), with a surface area of 3035 ha, is the busiest container port in the United States, dealing with one-quarter of all cargo entering the country. To meet development needs, projects linked to infrastructure improvement and maintenance are necessary. These can impact sensitive habitats, such as the Inner and Outer Harbor, as well as eelgrass habitats and wetlands under federal jurisdiction. With the aim of mitigating its global effects on the environment, the port considered developing an Umbrella Mitigation Bank Agreement to take into account impacts before they occur [27]. Previously, the port had created four mitigation banks: Inner Harbor mitigation bank, Outer Harbor mitigation bank and the off-site ${ }^{4}$ mitigation banks of the Batiquitos and Bolsa Chica lagoons. These banks are allowed to obtain credits only for losses related to US Waters and Essential Fish Habitats. They are qualified as 'single user' or 'single client' banks since they were developed for and are used by a unique entity in order to provide offsets exclusively for its own authorized impacts.

\section{a. Harbor mitigation banks}

The memorandum of understanding establishing the Harbor mitigation banks was signed by the City of Los Angeles Harbor Department, USFWS, CDFW and NMFS. Agencies such as the EPA, the California State Lands Commission (CSLC), the California Coastal Commission and the USACE were not involved in the negotiations [28]. The impacts on listed species were not covered by the memorandum. The banks were planned to be active until all credits were used or until the abrogation of the banks following the agreement of all signatory parties of the memorandum.

The Inner Harbor mitigation bank was established in 1984 to offset impacts related to construction projects involving excavation or filling within the Inner Harbor [29]. It provides in-kind offsets for spatial and

\footnotetext{
${ }^{4}$ These offset sites are not located in the same area as the impacted site.
} 
temporal losses of marine habitats with a 1:1 ratio - excavation generates credits, while filling removes them.

The Outer Harbor mitigation bank was created in 1997 to provide partial offsetting for impacts generated by a dredging and filling program for Pier 400 as well as other dredging and filling projects within the port [30]. The Outer Harbor has marine habitats of a higher quality than those of the Inner Harbor, thus the Outer Harbor bank was established for out-of-kind offsets according to various ratios depending on the location of impacts (ratios are based on expert assessments).

\section{b. Off-site mitigation banks}

\section{Batiquitos Lagoon}

Batiquitos Lagoon is an area of coastal wetlands with a surface area of 241 ha near the city of Carlsbad (90 $\mathrm{km}$ south of the Port of Los Angeles). It provides habitats for numerous aquatic and marine birds listed at state or federal levels. Following changes due to an increase in trade and transportation, the mouth of the lagoon became blocked, causing the basins to silt up and become shallower; the lagoon was expected to fill up within 50 years [31]. In 1987, a restoration program was developed to enhance lagoon habitats and reopen the wetlands to tidal action so that migratory birds would remain [32]. A memorandum of agreement, originated by the Outer Harbor mitigation bank to compensate for the dredging and filling of Pier 400 [32], was signed by the Harbor, the city of Carlsbad, CSLC, CDFW, USFWS and NMFS. The restoration work took place from 1994 to 1997. On completion of the work, the CSLC leased the lagoon to CDFW, which became responsible for its maintenance as an ecological reserve in perpetuity, as well as for its monitoring and management through a maintenance fund (secured in constant injections for 30 years). A second investment fund will take over after 30 years for a supposedly unlimited duration.

Only subtidal and intertidal habitats and low marshes were included in the calculation of the mitigation credits to maintain equivalence with lagoon areas. These credits can serve to compensate for impacts on deep-water Outer Harbor habitats with a ratio of 1.06:0.40 (Outer Harbor credit:compensatory ha at Batiquitos). Equivalence was calculated using a modified Habitat Evaluation Procedure (HEP).

However, the maintenance account, which was meant to last 30 years, has been totally depleted as the interest was lower than expected due to the economic crisis of 2008. The investment fund is not yet available, making conservation management actions challenging.

\section{Bolsa Chica lowlands}

The Bolsa Chica lowlands are an area of coastal wetlands with a surface area of 505 ha. They are located 21 $\mathrm{km}$ southeast of the Port of Los Angeles and provide habitats for fish, aquatic and marine birds and listed birds. Various human activities (including oil extraction and flood control systems) have altered the landscape and its hydrology, cutting off tidal flow to the area and filling up most of the wetlands.

Following the mobilization of environmental groups, Bolsa Chica was identified as a potential restoration site, and the Ports of Los Angeles and Long Beach pinpointed these wetlands as a potential offset site for their development projects. A memorandum of understanding was signed in 1995. Amendments to this granted additional credits to the Port of Los Angeles for the restoration of tidal action [33, 30]. A third amendment in 2005 established the restoration of the muted tidal areas in exchange for additional credits [34]. Under the memorandum, 143.3 ha of subtidal, intertidal and low marsh habitats were restored for a total of 454 mitigation credits (each port received half of the credits; the Port of Los Angeles credits were 
for the Outer Harbor). The second and third amendments provided 40 and 38 credits respectively for the restoration of the full tidal basin and muted tidal areas.

The restoration work was undertaken from 2004 to 2006. The USFWS is responsible for the maintenance of the site as a reserve in perpetuity, as well as for its monitoring and management. The ratio 1.32:1 (Outer Harbor:Bolsa Chica lowlands) for full tidal zones was determined on the basis of a similar project in terms of impact and restoration (Port of Long Beach Pier J/Anaheim Bay) in which a combination of Habitat Evaluation Procedure and Habitat Equivalency Analysis was used. Concerning the muted tidal zones, the ratio was reduced to 0.44:1 (Outer Harbor:Bolsa Chica lowlands) (as these ecosystems produce one-third less fish than full tidal ecosystems).

\section{c. Multi-habitat Umbrella Mitigation Banking Agreement (UMBA)}

More recently, the Port of Los Angeles proposed the development of a multi-habitat Umbrella Mitigation Banking Agreement (UMBA), given the need to update the Inner and Outer Harbor mitigation banks in order to be compliant with the Final Rule of 2008 (the initial memorandums of the Harbor banks had not been signed by the USACE and the EPA).

The aim of the UMBA was to create a system under which the port could obtain credits for impacts on Inner and Outer Harbor habitats or on eelgrass and wetlands under federal jurisdiction. Another aim was to provide a framework for potential off-site and out-of-kind banks. These could then provide additional mitigation credits for current and future extension projects and for maintenance activities. The main challenge of out-of-kind mitigation was considered to be determining functional equivalence between impacted and restored habitats. The methodology selected for this was in line with Habitat Equivalency Analysis [18]. Opportunities for out-of-kind compensation included the restoration of sensitive habitats such as coastal wetlands and rocky coasts.

Initially the plan was to draft the UMBA as a common document with the USACE, EPA, USFWS, CDFW, NFMS and the Coastal Commission. But the project was abandoned when the USACE could not come to a legal agreement with the other agencies, which wanted to keep their independence. These agencies have different priorities and their mitigation requirements can diverge. For instance, in the case of impacts on eelgrass, the USACE applies its checklist regarding mitigation ratios before making a decision and issuing a permit. The USACE can also rely on the ratio defined in the 'California Eelgrass Mitigation Policy and Implementing Guidelines', or, if it considers that the ratio in this policy is insufficient or too high, it can conduct a review process of the Essential Fish Habitat with the NMFS. In the case of unvegetated shallow zones, the NFMS considers these as potential eelgrass habitats and thus offset zones, while the USACE disagrees with this (Section 404 of the Clean Water Act does not list unvegetated sand as a Special Aquatic Site).

According to different interviewees, one of the unexpected positive outcomes of the ultimately abandoned development process of this offset instrument was that these agencies were for the first time required to negotiate on the perimeters of their jurisdictions. This allowed them to learn the priorities of each entity and evaluate their room for manoeuver. Constraints such as these often shape the decisional patchwork related to offsetting. 
The Southern California Wetlands Recovery Project (SCWRP) is a broad-based partnership of 18 state and federal resource management agencies working in concert with scientists, local governments, environmental organizations, business leaders and educators. It was created in 1997 to improve coordination between different agencies, to pool resources and to promote wetland restoration within the Southern California region extending from Point Conception (in Santa Barbara County) south to the border with Mexico.

The structure of the SCWRP consists of a Board of Governors (a decision-making organ), a Wetland Managers Group, and a consultative scientific committee that includes researchers and restoration practitioners. The California State Coastal Conservancy provides staff and serves as a finance office. The SCWRP tends to employ a watershed approach, aiming to preserve and restore not just wetlands as defined by regulatory agencies, but also adjacent shallow subtidal habitats, historic wetlands, areas fringing wetlands, and uplands in order to ensure functional systems. The restoration projects are developed in collaboration with local and regional agencies and NGOs.

In cases in which authorized impacts (according to Section 404, Clean Water Act; Section 10, Rivers and Harbors Act; Final Rule: Parts 325 and 332, 33 Code of Federal Regulations and Part 230, 40 Code of Federal Regulations) cannot be offset appropriately through mitigation banks (i.e. in the absence of a bank delivering credits of the same nature as the impacts), in-lieu fee mitigation can be used preferentially over permittee-responsible mitigation, in particular when this better serves watershed priorities. The use of inlieu fee mitigation is at the discretion of signatory agencies (or the agencies constituting the Interagency Review Team) during the permit application process on a case-by-case basis. The Interagency Review Team for the SCWRP In-Lieu Fee Program consists of members from the USACE, EPA, NMFS, USFWS, Coastal Commission, CDFW, State Water Board ${ }^{5}$, Los Angeles Water Board, Santa Ana Water Board, and San Diego Water Board. This team is responsible for supervising the establishment, use, operation and maintenance of the SCWRP in-lieu fee mitigation program [35].

Negotiations on the SCWRP in-lieu fee mitigation program started in 2012 and were due to be completed by the end of 2016. The program's priorities are to:

- Provide an opportunity to pool resources into projects that present better outcomes in terms of ecological function than small-scale, and geographically isolated projects

- Use scientific and technical resources established through the SCWRP

- Formalize the watershed approach in order to identify the most appropriate offset options in a nonfragmented manner

- Reduce uncertainties concerning the success of offset projects

- Achieve regulatory requirements more effectively

In-lieu fee projects will be selected from projects on the SCWRP's Work Plan. SCWRP Work Plan projects reflect the priorities and regional objectives of the SCWRP's Regional Strategy, which has been approved by the 18 member agencies of the Wetland Managers Group and SCWRP's Board of Governors. Potential in-lieu fee projects off the Work Plan will first be assessed according to ecological and political feasibility criteria,

${ }^{5}$ The State Water Board coordinates the actions of the nine Regional Water Quality Control Boards in California and is responsible for the protection of water bodies. Each Regional Water Board's area of activity corresponds to a watershed. 
then further refined in consultation with the in-lieu fee program's Interagency Review Team, who must approve a Mitigation Plan for every project to be completed under the in-lieu fee program. The SCWRP inlieu fee program instrument defines multiple sub-service areas ${ }^{6}$ within the overall service area of the program. Each in-lieu fee project is selected within a sub-service area in order to take into account factors linked to the vicinity of the watershed, its position in the landscape and the wetland's functionalities.

The sponsor of the SCWRP's in-lieu fee mitigation program is the Coastal Conservancy, which is legally responsible for an offset after the sale of in-lieu fee credits to a permittee. The Coastal Conservancy can establish a contract or an agreement with a third party (e.g. an NGO or private or public sector entity) for the development, implementation and/or long-term management of a project. Long-term management requires site protection (e.g. a conservation easement ${ }^{7}$ ) and a liability shift to another organization.

The Coastal Conservancy will establish an account to receive the funds stemming from the sale of credits, and these funds will be used for the full costs of a project, including its design, acquisition, implementation, monitoring and management, as well a financial assurances, contingency funds, and administrative costs of the Coastal Conservancy. A separate account will be established for the long-term management and maintenance of the site.

The number of credits generated by each offset project will be calculated on the basis of the number of acres or the functionality unit, and the credits will be classified in terms of habitat or resource type, jurisdictional status, and offset type (i.e. enhancement, rehabilitation, recreation, creation or preservation). Credits will be available for tidal and non-tidal aquatic resources. The California Rapid Assessment Method (CRAM) will be used to assess the initial state of a wetland when evaluating the opportunity to implement offsetting. This method can also be employed to evaluate performance standards after offsetting, coupled with a level $3^{8}$ intensive site-specific assessment and/or alternative functional assessment methods. For each in-lieu fee project, the required method used to determine the credits will be specified in consultation with signatories. The USACE will define the number of available credits for each project on the basis of the recommendations of the program signatories. The conditions for issuing the credits will be specified for each offset project.

Concerning credits linked to preservation, all the anticipated credits will be deemed to be generated upon the acquisition and full legal protection of the property to be preserved and the implementation of the longterm management and maintenance fund for such property.

\section{Results: Using ANT to analyze the California case studies}

To analyze the governance models developed in California to devise offset instruments for authorized impacts on marine zones, ANT was used (Error! Reference source not found.). The different elements of ANT (non-human actants, spokesperson actants, other human actants, potential positive or negative modalities, translation elements, obligatory passage point) explaining organizational dynamism were identified in each case study.

Table 1 here

\footnotetext{
${ }^{6}$ The service and sub-service areas define the areas within which an impact on US Waters and/or State Waters must be located to be offset through the credits of the in-lieu fee program.

${ }^{7}$ A conservation easement is a legal tool that limits in perpetuity human development on a defined area of land but may allow certain light uses (e.g. hiking).

${ }^{8}$ The EPA refers to a three-tier framework for wetlands monitoring and assessment. Level 3, or intensive site assessment, provides a thorough measure of the state of a wetland, based on biological taxa and/or hydro-morphological functions.
} 
The organization of socio-ecological system (the relation between the different actants, their capacity to call upon different modalities) informs the progress of the translation processes. These processes turn out to differ according to the existence of controversies around the representation of nature among stakeholders. Two different patterns were identified. These are referred to as "consensual" when the translation process relies on commonly recognized modalities (status, sizing methodologies, restoration techniques) and as "innovative strategies" when the translation process calls upon 'skilled intermediaries' and new modalities (spatial and time scales) in order to establish the obligatory passage point, that is, the marine offset instruments.

\subsection{Consensual process}

\subsubsection{Representation of nature}

During these interviews, it was mentioned several times that wetlands are the easiest case to deal with in terms of offsetting. The obligatory passage points concerning wetlands offsetting have been well established in the United States since the 1980s. The No Net Loss principle emerged from the National Wetland Policy Forum in 1987 and was adopted by the administration in 1989 [36]. The regulations related to wetlands protection have now been applied for a number of years, so the objectives are clearly defined and the points of view on the subject do not significantly diverge. Wetlands in the United States benefit from offset instruments such as mitigation banks $[37,38,39]$ that rely on standardized assessment methodologies such as Rapid Assessment Methods [40] and referenced restoration techniques [41, 42]. This situation tends to favor out-of-kind offsetting for marine impacts in favor of coastal wetlands, thus it could be considered that out-of-kind offsetting is implemented at the expense of purely marine ecosystems. Examples are compensating the impacts of SONGS on Southern California Bight fish in open water with the San Dieguito lagoon, or compensating the impacts of the Port of Los Angeles with the Bolsa Chica and Batiquitos lagoons. But it is also important to stress that $90 \%$ of Californian wetlands with a high biodiversity stake have disappeared over the past century due to human activities (USFWS). It is this critical situation that triggered the implementation of California environmental policies on wetlands conservation.

It is clear that agencies can more easily agree when conservation objectives are clearly stated, which is the case for protected species or habitats when sizing methodologies and technical solutions are available (which is the case for wetlands and eelgrass habitats). Human 'actants' influence the integration of nonhuman 'actants'. When a consensus exists, illustrated by clearly defined conservation objectives in environmental regulations, this leads to a certain representation of nature. As mentioned by Latour, B. [5] for science 'in the making' (and not for proven facts), 'given that the settlement of a controversy is the cause and not the consequence of the representation of nature, one cannot invoke the final outcome - nature - to explain how and why a controversy was settled'.

\subsubsection{Positive modalities: drivers of offsetting}

Within this representation of nature, the protection status of the considered habitat or species (here, Essential Fish Habitats, Habitat Areas of Particular Concern or Special Aquatic Sites) constitutes a positive modality. These habitats or species benefit from consensus as regards their protection. This is particularly 
true for eelgrass and wetlands in the case studies reviewed here. This results in sizing methodologies that are adapted to these species and the pressures on them, such as the Rapid Assessment Method developed for wetlands in the United States, or Habitat Equivalency Analysis used for the sizing of eelgrass offsetting for authorized impacts. In coastal zones, available restoration techniques mainly concern wetlands [41] and marine and coastal 'ecosystem engineer' species such as seagrass and macroalgae [43, 52]. Thus, the protection status of an area, robust sizing methods and proven restoration techniques constitute positive modalities that foster integration of tacit knowledge and its incorporation within a mitigation instrument. These modalities are closely related to 'impacted elements' and 'generated pressures' actants.

\subsubsection{Translation process}

Next, those involved in making the case by building up facts must 'translate' their message, facilitating its interpretation so their interest aligns with the interests of others recruited in the process [5]. In the case of eelgrass mitigation policy, eelgrass represents a suitable habitat for numerous species under the Endangered Species Act (which interests the USFWS and CDFW), is listed as an Essential Fish Habitat and a Habitat Area of Particular Concern under the Magnusson-Stevens Act (which interests the NMFS), and as a Special Aquatic Site under the Clean Water Act (which interests the EPA and USACE). For this reason, the translation process in this case was not a stumbling block; the aims of the different agencies were aligned and consistent. The NMFS acted as the linchpin as it is responsible for marine resources and the management of their habitats, in particular concerning Essential Fish Habitats and Habitat Areas of Particular Concern. Furthermore, some flexibility in the recommendations was voluntarily maintained so that the guidelines could be adapted to the various technical abilities of environmental consultancies.

\subsection{Innovative strategies}

However, some processes in the development of mitigation guidelines fall outside the consensual framework. Analyzing these can reveal the finer mechanisms involved in devising different offsetting governance models. These mechanisms are useful in understanding how some of the original issues are resolved in the boundaries of the use of a methodology or the prerogatives of stakeholders.

\subsubsection{A lack of consensus: the role of 'skilled intermediaries'}

In the case of situations in which stakeholders have contrasting interests and no consensus exists, new strategies may need to be employed.

In the case of SONGS, the Coastal Commission played an initiating role, imposing additional conditions for permit approval and establishing an independent committee, the Marine Committee Review. This committee then intervened by requiring impacts to be identified by independent scientists, enabling the existing stakeholders to be reconfigured through a process of deconstruction and reconstruction. The creation of an independent committee and the requirement of an evaluation by independent scientists were crucial in redistributing stakeholder interests and co-constructing new common goals. In the case of the Port of Los Angeles, the harbor authority played a driving role in developing the UMBA, acknowledging the need to take into account potential impacts before impacts occurred, but it did not have a regulatory role. In the case of the SCWRP's in-lieu fee mitigation project, the Coastal Conservancy highlighted the opportunity to link wetland restoration objectives to potential impacts on the Californian coast. From there, its 
Interagency Review Team, a concertation body including federal, state and regional environmental agencies, will take over to supervise the establishment, use, operation and maintenance of a mitigation project. These cases indicate the importance in the process of 'skilled intermediaries' or 'policy entrepreneurs' who are capable of 'forging associations between important actors, explaining the potential utility of the assessment framework to other local actors, and addressing negative modalities' [8]. They can act as guarantors of the interests of a threatened ecological system that does not benefit from a consensus. These intermediaries appeal to new modalities that go beyond the traditional framework (see 4.2.2).

\subsubsection{Beyond existing modalities}

In the case of eelgrass mitigation, the guidelines initially applied only to southern California, and were then extended throughout the state. This change in spatial scale, corresponding to a relevant biogeographical unit, facilitated the process of developing the mitigation policy. It allowed stakeholders to consider the issue at the scale of California, where activities impacting eelgrass are similar, even if local particularities need to be taken into account since both pressures and growth characteristics can differ locally. This enabled going beyond a case-by-case approach, to pool knowledge and improve effective decision-making. In the case of the SCWRP's in-lieu fee mitigation project, the scale corresponds to that of the SCWRP, which is equivalent to protected wetlands in southern California divided into three sub-service areas on the basis of functional considerations and economic viability. In the case of SONGS, it was a change in temporal scale that was crucial; firstly, ad hoc monitoring before and after the first two years of the operational phase in order to determine the impacts (a process that is currently little developed), secondly, a five-year monitoring period of the experimental phase involving the creation of an artificial reef to define an appropriate offset project. This temporal rescaling is indicative of an adaptive response that is able to evolve according to need. In the eelgrass and SCWRP case studies, long-term feedback from existing projects facilitated the development of suitable mitigation instruments.

These unique modalities adapted to their specific cases challenge the existing approaches, demonstrating that these practices can be redesigned by generating innovative approaches in the development of offset instruments.

\subsubsection{The translation process and negative modalities}

In the case of the Port of Los Angeles's attempt to create an Umbrella Mitigation Bank Agreement, developing a common document between all agencies that concerned different impacted elements required the USACE to recruit the other agencies to their own objectives. Although the port played a driving role, as the initiator behind brainstorming an agreement, it did not have a regulatory role. The consequent impossibility of reallocating interests and objectives, leading to the abandonment of the project, seems to have stemmed from a poor knowledge of the leeway of each agency in issues related to offsetting authorized environmental impacts. Indeed, the development of this mitigation instrument was a first in terms of the number of participating agencies in negotiations regarding marine offset issues: the USACE, EPA, USFWS, CDFW, NMFS and the Coastal Commission. This situation illustrates the dilemma referred to by Cowell and Lennon [8] in which 'enrolling actors with divergent policy agendas can also lead to new assessment methodologies being confined to modest, informational uses, exerting little immediate leverage over business as usual. Conversely, asserting that a particular methodology must be accepted, or that the knowledge generated has nonnegotiable consequences for existing policies, invites negative modalities- 
resistance and rejection.' Setting in stone an obligation to refer to a certain sizing methodology can be a deterrent for some partner agencies that fear losing their influence in negotiations (this is less important in cases where an official method is already established). The issue encountered by the Port of Los Angeles is similar to that described by Mann and Absher [44] in the context of the creation of a conservation bank ${ }^{9}$ in California. These authors argue that the culture of the involved agencies and the specific context allow the development of new and potentially controversial tools. They observed that management mechanisms aiming at ensuring the bank would correspond to local ecological and socio-economic conditions turned into a negotiation process on juridical terms and a review process of models in order to secure the agencies' institutional provisions. However, in the case of the Port of Los Angeles, the arguments were mainly jurisdictional and did not allow opposition to be overcome, thus they turned into negative modalities. They did not prove to be effective in the translation process.

\subsection{Obligatory passage point}

In the case of the statewide eelgrass mitigation policy, guidelines were developed to which the USACE and Coastal Commission can refer for issuing permits. In the case of SONGS, offsetting solutions adapted to the project were listed in the amended operation permit. In the case of SCWRP, in-lieu fee mitigation can be recommended in the framework of permits delivered by different signatory agencies in southern California (there is a soft preference by regulators for in-lieu fee mitigation as a second choice after mitigation banking). Thus, 'when strategies succeed, the fact that has been established becomes essential: this is an obligatory passage point for those who want to act according to what their interests dictate to them' [5].

In the case of the Port of Los Angeles, the multi-habitat Umbrella Mitigation Bank Agreement was abandoned - only the compliance of the two preceding Harbor mitigation banks was ensured. For future impacts, either a case-by-case offset will have to be developed for impacts other than those on US Waters and Essential Fish Habitats, or a new bank may be created for impacts on US Waters or Essential Fish Habitats according to the appropriate procedure.

The analysis of these four case studies confirmed the initial assumption of the importance of the ecological system on governance systems. Yet looking at the process of the development of these governance systems through the lens of ANT shines light on the complexity of this link; in particular, on the network involved in designing a relevant offset instrument. The ANT highlights the essential steps in attaining the obligatory passage point: the involvement of 'skilled intermediaries' and the modalities used in the translation process. The different elements involved in these steps are summarized in Error! Reference source not found.1.

\section{Fig 1 here}

As this diagram shows, 'skilled intermediaries', often stemming from the reconfiguration of stakeholders, can succeed in overcoming uncertainties generated by negative modalities and in leading all stakeholders in the network towards the obligatory passage point. They draw upon effective translation processes that they contribute to establishing. The translation process can include new modalities that represent adaptive solutions: for example, a change in spatial or temporal scale.

\footnotetext{
${ }^{9}$ A conservation bank is a parcel of land with conservation value that is protected in perpetuity. In exchange for conserving and managing the land for species that are endangered, threatened or candidates for listing as endangered or threatened, the conservation bank is authorized to sell credits to permittees.
} 


\section{Discussion: towards a reconfiguration of environmental governance}

This analysis of the governance processes underlying the emergence of offset instruments in California allows a better understanding of the links between the different 'actants' (according to ANT) in the mitigation network. The findings confirm the important role of previously acknowledged elements such as impacted ecosystems, sizing methodologies and ecological engineering techniques. In addition, they highlight the key role of certain more discreet factors: the intervention of 'skilled intermediaries' and the crucial interactions of spatial and time scales. This calls for a rethinking of the marine offset governance.

The issue of reconfiguring environmental governance in terms of stakeholder networks and temporal and spatial scales (the expression is borrowed from the title of a study by Bulkeley [45]: 'Reconfiguring environmental governance: Towards a politics of scales and networks') has been tackled several times in geography studies. This was also the case in the study by Mann and Absher [44] concerning the development of mitigation banks as a policy instrument from a socio-ecological system and environmental governance perspective. An analysis of these processes reveals tensions between requirements concerning adaptation, context specificities and harmonization that must be overcome in order to reach common policy objectives, particularly in the case of divergent goals between stakeholders [46].

\subsection{Stakeholder reconfiguration}

In the California case studies, a tendency to create new arrangements that include existing environmental agencies or other stakeholders but in new forms has been observed: for example, specific structures such as the Marine Committee Review and the Interagency Review Team. Thus one possible response to divergent interests can be to reconfigure representatives from pre-existing organizations to build a collaborative answer to an emergent issue [47].

The involvement of stakeholders other than federal or state agencies has also been noted, such as the integration of NGOs (e.g. Friends of the Earth in the SONGS case study, SCWRP for the in-lieu fee case study), developers (e.g. SONGS, Port of Los Angeles), environmental consultancies (e.g. guidelines for eelgrass mitigation), scientists (e.g. SONGS, guidelines for eelgrass mitigation, SCWRP). This is in line with the observations of Karkkainen [48], who, while acknowledging the pivotal role of government agencies, mentions that environmental issues have become too complex to be solved through the direct, independent actions of the government (a 'top-down' approach). He supports the involvement of different sets of stakeholders in ongoing, cross-party collaboration and concerted action (a horizontal approach). These stakeholders could include government agencies, regional or local governments, multilateral institutions, intergovernmental entities, NGOs, private sector representatives and independent scientists.

Bulkeley [45] encourages the development of approaches to environmental governance that 'can move beyond nested hierarchies ${ }^{10}$, the separation of levels of decision-making, and the divisions between territorially bound states and the fluid relations of non-state actors'. The objective is to leave room for hybrid governance arrangements, based on a truism in human geography, where scales are socially and politically constructed and thus contested $[49,50]$.

Lastly, the intervention of skilled intermediaries supported the idea that some actors or institutions have the capacity of formulating, ensuring and implementing specific policies while others do not [51].

\footnotetext{
10 'Hierarchy' in the sense of classifying items according to their relative importance and their inclusive character.
} 
These results share similarities with feedbacks from Integrated Coastal Zone Management (ICZM) and Marine Spatial Planning (MSP) processes. These tools have been widely used to promote new approaches for the management of coastal and marine territories. They usually mark a shift from a regulatory and centralized system towards a system stemming from territorial initiative and local governance [53]. Mixing top-down and bottom-up approaches, they enable different levels of integration. They are usually seen as a dynamic process involving government and society, scientists and decision-makers, public and private interests for the development and the protection of coastal and marine resources [54]. Marine offset governance should rely on the development of relevant governance units, implemented at a relevant spatial scale in line with that of the issues faced, integrating a longer timeframe and promoting adaptive solutions. The experience gained through the implementation of ICZM or MSP initiatives with a reorganization of environmental governance can thus inform the development of marine offsetting schemes.

\section{References}


[1] Jacob, C., Quétier, F., Aronson, J., Pioch, S. and Levrel, H., 2015. Vers une politique française de compensation des impacts sur la biodiversité plus efficace: défis et perspectives. VertigO - la revue électronique en sciences de l'environnement. 14(3).

[2] Boisvert, V., 2015. Conservation banking mechanisms and the economization of nature: an institutional analysis. Ecosystem Services. 1-9

[3] Scemama, P., Levrel, H., 2014. L'émergence du marché de la compensation aux États-Unis: changements institutionnels et impacts sur les modes d'organisation et les caractéristiques des transactions. Revue d'Economie Politique. 123, 1-32.

[4] Vaissière, A.C., Levrel, H., 2015. Biodiversity offset markets: what are they really? An empirical approach to wetland mitigation banking. Ecological Economics. 110, 81-88.

[5] Latour, B., 1987. Science in action: How to follow scientists and engineers through society. Harvard university press. $288 \mathrm{p}$.

[6] Miossec, A., 1994. Les côtes atlantiques des Etats-Unis à l'épreuve du Coastal Zone Management Act. Norois. 161(1), 35-53.

[7] Callon, M., 1986. Some elements of a sociology of translation: domestication of the scallops and fishermen of St Brieuc Bay, in Power, Action and Belief: A New Sociology of Knowledge? Ed. J Law (Routledge, London) pp 196-233

[8] Cowell, R. and Lennon, M., 2014. The utilisation of environmental knowledge in land-use planning: drawing lessons for an ecosystem services approach. Environment and Planning C: Government and Policy. $32(2), 263-282$.

[9] Robertson, M., 2012. Measurement and alienation: making a world of ecosystem services. Transactions of the Institute of British Geographers. 37(3), 386-401.

[10] Collins, A, Cowell, R, Flynn, A, 2009. Evaluation and environmental governance: the institutionalisation of ecological footprinting. Environment and Planning A. 41 1707-1725.

[11] Murdoch, J, 1998. The spaces of actor-network theory. Geoforum. 29 357-374.

[12] Degeling, P, 1995. The significance of 'sectors' in calls for urban public health intersectoralism: an Australian perspective. Policy and Politics. 23(289), 301.

[13] Himley, M., 2008. Geographies of environmental governance: The nexus of nature and neoliberalism. Geography Compass. 2(2), 433-451.

[14] Cowell, R., Ellis, G., Sherry-Brennan, F., Strachan, P.A., Toke, D., 2015. Rescaling the Governance of Renewable Energy: Lessons from the UK Devolution Experience. Journal of Environmental Policy \& Planning. 1-23.

[15] Jacob, C., Pioch, S., Thorin, S., 2016. The effectiveness of the mitigation hierarchy in environmental impact studies on marine ecosystems: A case study in France. Environmental Impact Assessment Review. 60, 83-98.

[16] Robertson, M., 2010. Performing environmental governance. Geoforum. 41(1), 7-10. 
[17] NMFS, 2014. California Eelgrass Mitigation Policy and Implementing Guidelines

[18] King, D.M. and Price, E.W., 2004. Developing Defensible Wetland Mitigation Ratios: A Companion to "The Five-step Wetland Mitigation Ratio Calculator." Prepared by King and Associates, Inc. for NOAA, Office of Habitat Conservation, Habitat Protection Division.

[19] Evans, N.T. and Short, F.T., 2005. Functional trajectory models for assessment of transplanted eelgrass, Zostera marina L., in the Great Bay Estuary, New Hampshire. Estuaries. 28(6): 936-947.

[20] Fonseca, M.S., Kenworthy, W.J, Colby, D.R., Rittmaster, K.A., Thayer, G.W., 1990. Comparisons of fauna among natural and transplanted eelgrass Zostera marina meadows: criteria for mitigation. Marine Ecology Progress Series. 65, 251-264

[21] Hoffman, R.S. 1986. Fishery Utilization of Eelgrass (Zostera marina) Beds and Non-vegetated Shallow Water Areas in San Diego Bay. SWR-86-4, NMFS/SWR.

[22] Permit amendment, 1997. Adopted findings and conditions permit amendment and condition compliance, Permit 6-81-330-A (SONGS Units 2 \& 3).

[23] Ambrose, R.F., 1994. Mitigating the effects of a coastal power plant on a kelp forest community: rationale and requirements for an artificial reef. Bulletin of Marine Science. 55(2-3), 694-708.

[24] Deysher, L.E., Dean, T.A., Grove, R.S., Jahn, A., 2002. Design considerations for an artificial reef to grow giant kelp (Macrocystis pyrifera) in Southern California. ICES Journal of Marine Science: Journal du Conseil. 59(suppl), S201-S207.

[25] Reed, D., Schroeter, S., Page, M., 2016. 2015 Annual Report of the Status of Condition C: Kelp Reef Mitigation. San Onofre Nuclear Generating Station (SONGS) Mitigation Program Submitted to the California Coastal Commission. Marine Science Institute, University of California Santa Barbara

[26] Page, M., Stephen Schroeter, S., Reed D., 2016. Annual Report of the Status of Condition A: Wetland Mitigation San Onofre Nuclear Generating Station (SONGS) Mitigation Program Submitted to the California Coastal Commission. Marine Science Institute, University of California Santa Barbara

[27] Anchor QEA, 2012. Port of Los Angeles mitigation bank draft mitigation banking credit valuation approach.

[28] Hartmann, J., 2000. The Southern California Wetlands Recovery Project: The Unfolding Story. Golden Gate University Law Review. 30(4), 885-967. Accessed October 30, 2016. Available from: http://digitalcommons.law.ggu.edu/ggulrev/vol30/iss4/4/

[29] City of Los Angeles Harbor Department et al. (U.S. Army Corps of Engineers, U.S. Environmental Protection Agency, National Marine Fisheries Service, U.S. Fish and Wildlife Service, California Department of Fish and Game, California Coastal Conservancy, California Resources Agency, California State Lands Commission, City of Los Angeles, City of Long Beach), 1984. Memorandum of Understanding Among the Harbor Department of the City of Los Angeles, CDFG, NOAA, and USFWS, to Establish A Procedure for Advance Compensation of Marine Habitat Losses Incurred by Selected Port Development Projects within the Harbor District of the City of Los Angeles.

[30] City of Los Angeles Harbor Department et al. (U.S. Army Corps of Engineers, U.S. Environmental Protection Agency, National Marine Fisheries Service, U.S. Fish and Wildlife Service, California Department 
of Fish and Game, California Coastal Conservancy, California Resources Agency, California State Lands Commission, City of Los Angeles, City of Long Beach), 1997. Second Amendment to the Agreement to Establish a Project for Wetlands Acquisition and Restoration at the Bolsa Chica Lowlands in Orange County, California, for the Purpose, Among Others, of Compensating for Marine Habitat Losses Incurred by Port Development Landfills within the Harbor Districts of the Cities of Los Angeles and Long Beach, California.

[31] Bataquitos Lagoon Foundation, 2011. About Bataquitos Lagoon. Accessed October 30, 2016. Available at: http://www.batiquitosfoundation.org/about/

[32] Appy, R.G., no date. Mitigation: Concept to Reality. Accessed October 30, 2016. Available at: https://www.researchgate.net/publication/239922898_MITIGATION_CONCEPT_TO_REALITY

[33] City of Los Angeles Harbor Department et al. (U.S. Army Corps of Engineers, U.S. Environmental Protection Agency, National Marine Fisheries Service, U.S. Fish and Wildlife Service, California Department of Fish and Game, California Coastal Conservancy, California Resources Agency, California State Lands Commission, City of Los Angeles, City of Long Beach), 1996. First Amendment to the Agreement to Establish a Project for Wetlands Acquisition and Restoration at the Bolsa Chica Lowlands in Orange County, California, for the Purpose, Among Others, of Compensating for Marine Habitat Losses Incurred by Port Development Landfills within the Harbor Districts of the Cities of Los Angeles and Long Beach, California.

[34] City of Los Angeles Harbor Department et al. (U.S. Army Corps of Engineers, U.S. Environmental Protection Agency, National Marine Fisheries Service, U.S. Fish and Wildlife Service, California Department of Fish and Game, California Coastal Conservancy, California Resources Agency, California State Lands Commission, City of Los Angeles, City of Long Beach), 2005. Third Amendment to the Agreement to Establish a Project for Wetlands Acquisition and Restoration at the Bolsa Chica Lowlands in Orange County, California, for the Purpose, Among Others, of Compensating for Marine Habitat Losses Incurred by Port Development Landfills within the Harbor Districts of the Cities of Los Angeles and Long Beach, California.

[35] Draft ILF, 2016. Southern California Wetlands Recovery Project, In-Lieu Fee program enabling instrument

[36] Hassan, F., Levrel, H., Scemama, P., Vaissière, A-C, Le cadre de gouvernance américain des mesures compensatoires pour les zones humides, in: Levrel H., Frascaria-Lacoste N., Hay J., Martin G., Pioch S. (eds.), Restaurer la nature pour atténuer les impacts du développement. Analyse des mesures compensatoires pour la biodiversité Editions QUAE, Versailles. 34-44.

[37] Ambrose, R. F., 2010. Wetlands mitigation in the United States: assessing the success of mitigation policies. Wetlands Australia Journal. 19(1), 1-27.

[38] Ambrose, R.F., Callaway, J.C., Lee S.F., 2007. An Evaluation of Compensatory Mitigation Projects Permitted Under Clean Water Act Section 401 by the California State Water Resources Control Board, 19912002. $184 \mathrm{p}$.

[39] Bendor, T.K., Riggsbee, J.A., Doyle, M., 2011. Risk and Markets for Ecosystem Services. Environmental science \& technology. 45(24), 10322-10330.

[40] Fennessy, S., 2004. Review of rapid methods for assessing wetland condition. EPA/620/R-04/009.

[41] Moreno-Mateos, D., Power, M.E., Comín, F.A., Yockteng, R., 2012. Structural and Functional Loss in Restored Wetland Ecosystems. PLoS Biology. 10(1), e1001247. 
[42] Zedler, J.B., 2000. Progress in wetland restoration ecology. Trends in Ecology \& Evolution. 15(10), 402407.

[43] Bayraktarov, E., Saunders, M.I., Abdullah, S., Mills, M., Beher, J., Possingham, H.P., Mumby, P.J., Lovelock, C.E., 2015. The cost and feasibility of marine coastal restoration. Ecological Applications. 26(4), 1055-1074.

[44] Mann, C., Absher, J.D., 2014. Adjusting policy to institutional, cultural and biophysical context conditions: The case of conservation banking in California. Land Use Policy. 36, 73-82.

[45] Bulkeley, H., 2005. Reconfiguring environmental governance: Towards a politics of scales and networks. Political geography. 24(8), 875-902.

[46] Paavola, J., Gouldson, A., Kluvánková-Oravská, T., 2009. Interplay of actors, scales, frameworks and regimes in the governance of biodiversity. Environmental Policy and Governance. 19(3), 148-158.

[47] Meadowcroft, J., 2002. Politics and scale: some implications for environmental governance. Landscape and urban planning. 61(2), 169-179.

[48] Karkkainen, B.C., 2004. Post-sovereign environmental governance. Global Environmental Politics. 4(1), 72-96.

[49] Brenner, N., 2001. The limits to scale? Methodological reflections on scalar structuration. Progress in Human Geography. 25(4), 591e614.

[50] Marston, S., 2000. The social construction of scale. Progress in Human Geography. 24, 219e242.

[51] Gibbs, D., 2006. Prospects for an environmental economic geography: linking ecological modernization and regulationist approaches. Economic Geography. 82(2), 193-215.

[52] Jacob C., Buffard A., Pioch S., Thorin S., (in press). Marine ecosystem restoration and biodiversity offset. Ecological Engineering.

[53] Miossec A., 1998. Géographie humaine des littoraux maritimes. CNED.

[54] Meur-Férec C., 2009. La GIZC à l'épreuve du terrain : premiers enseignements d'une expérience française. Vertigo - la revue électronique en sciences de l'environnement. Hors-série 5.

[55] Callon M., Latour B., Akrich M., 2006. Sociologie de la traduction : textes fondateurs. Presses des Mines. $401 \mathrm{p}$. 


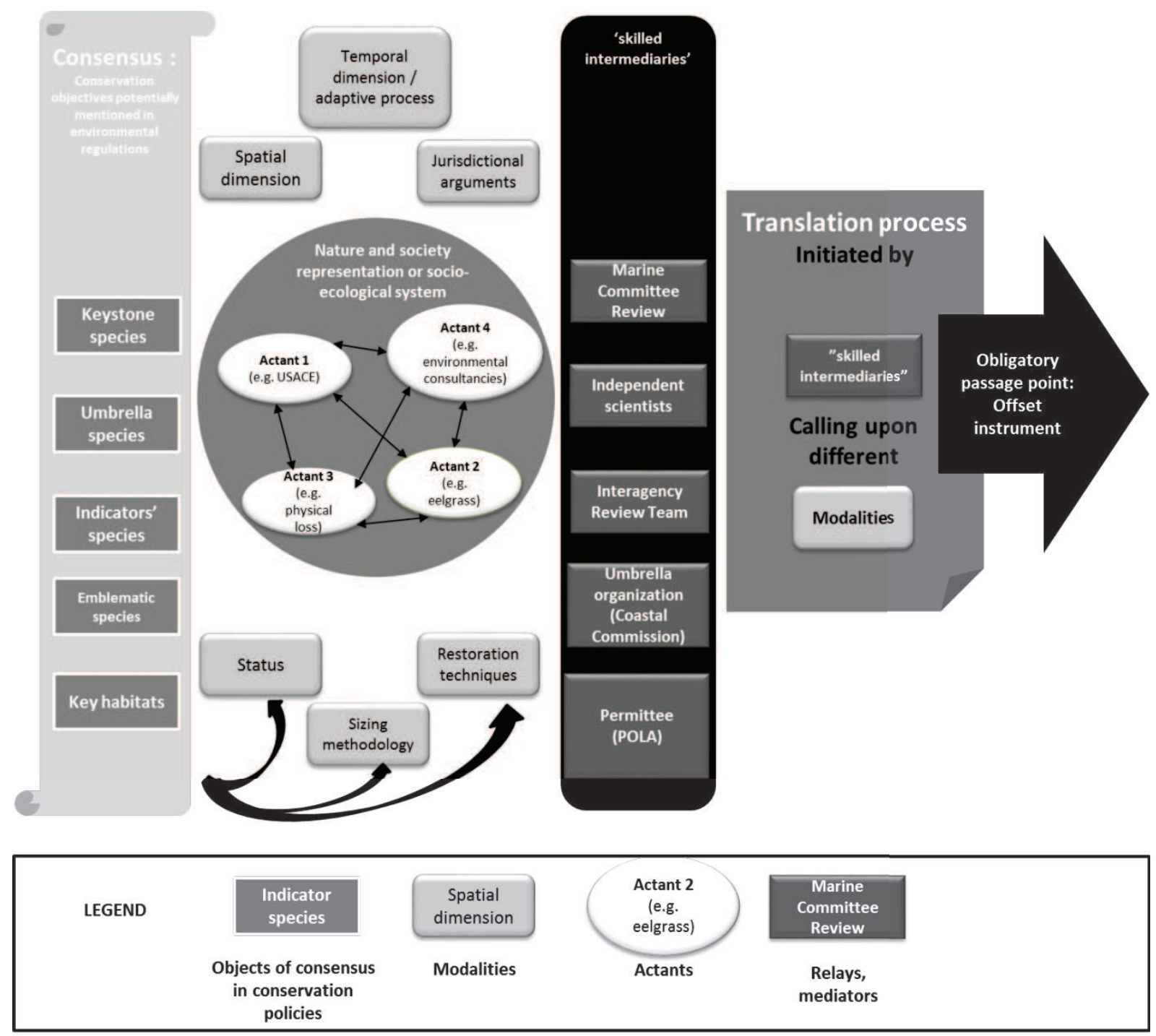


Figure 1: A diagram of the different elements and steps highlighted by ANT in the processes linked to the emergence of offset instruments within the marine realm (left to right) 
Table 1: Analysis of the four California case studies in terms of key elements as outlined in the ANT

\begin{tabular}{|c|c|c|c|c|c|}
\hline ANT elements & $\begin{array}{c}\text { Element } \\
\text { description }\end{array}$ & $\begin{array}{c}\text { Case study 1: California Eelgrass } \\
\text { Mitigation Policy }\end{array}$ & $\begin{array}{c}\text { Case study 2: San Onofre Nuclear } \\
\text { Generating Station offsetting }\end{array}$ & $\begin{array}{c}\text { Case study 3: Port of Los Angeles } \\
\text { offsetting }\end{array}$ & $\begin{array}{l}\text { Case study 4: SCWRP in-lieu fee } \\
\text { program }\end{array}$ \\
\hline \multirow[t]{2}{*}{$\begin{array}{l}\text { Non-human } \\
\text { actants }\end{array}$} & Impacted element & Eelgrass & Macroalgae and fish & Shallow waters, eelgrass, wetlands & $\begin{array}{l}\text { Wetlands, other US Waters, State } \\
\text { Waters }{ }^{1} \text {, aquatic resource buffer zones } \\
\text { and non-buffer upland habitats }\end{array}$ \\
\hline & Pressure & $\begin{array}{l}\text { Multiple (dredging, filling, turbidity, } \\
\text { shading, nutrient loading, etc.) }\end{array}$ & $\begin{array}{l}\text { On macroalgae: hydrological } \\
\text { modifications, thermic discharge, } \\
\text { turbidity } \\
\text { On fish: entrainment and } \\
\text { impingement of larvae through water } \\
\text { intake and loss of macroalgae habitat }\end{array}$ & $\begin{array}{l}\text { Physical loss or damage (due to } \\
\text { dredging and filling) }\end{array}$ & Multiple \\
\hline $\begin{array}{l}\text { Spokesperson } \\
\text { human actants }\end{array}$ & $\begin{array}{l}\text { 'Skilled } \\
\text { intermediaries' or } \\
\text { 'policy } \\
\text { entrepreneurs' }\end{array}$ & NMFS & $\begin{array}{l}\text { Coastal Commission, Marine } \\
\text { Committee Review ( } 3 \text { members: } 1 \\
\text { appointed by the Coastal Commission, } \\
1 \text { by the electric utility, } 1 \text { by an } \\
\text { opposing NGO) }\end{array}$ & Port of Los Angeles & Coastal Conservancy \\
\hline \multirow[t]{2}{*}{$\begin{array}{l}\text { Other human } \\
\text { actants }\end{array}$} & $\begin{array}{l}\text { Other involved } \\
\text { agencies }\end{array}$ & $\begin{array}{l}\text { USFWS, EPA, USACE, Coastal } \\
\text { Commission }\end{array}$ & NMFS, USFWS, CDFW & $\begin{array}{l}\text { USACE, EPA, USFWS, CDFW, NMFS, } \\
\text { Coastal Commission }\end{array}$ & $\begin{array}{l}\text { Interagency Review Team (USACE, } \\
\text { EPA, NMFS, USFWS, Coastal } \\
\text { Commission, CDFW, State Water } \\
\text { Board, Los Angeles Water Board, } \\
\text { Santa Ana Water Board, San Diego } \\
\text { Water Board) }\end{array}$ \\
\hline & $\begin{array}{l}\text { Other stakeholders } \\
\text { (permittees) }\end{array}$ & $\begin{array}{l}\text { None (private sector was not } \\
\text { involved) }\end{array}$ & $\begin{array}{l}\text { Southern California Edison (electric } \\
\text { utility) }\end{array}$ & Environmental consultancies & $\begin{array}{l}\text { SCWRP (broad partnership of state } \\
\text { and federal agencies working with } \\
\text { scientists, local authorities, NGOs, } \\
\text { companies, etc.) }\end{array}$ \\
\hline \multirow[t]{2}{*}{$\begin{array}{l}\text { Potential } \\
\text { modalities }\end{array}$} & Status & $\begin{array}{l}\text { Essential Fish Habitat, Habitat Area of } \\
\text { Particular Concern, Special Aquatic } \\
\text { Site }\end{array}$ & $\begin{array}{l}\text { For macroalgae: Essential Fish } \\
\text { Habitat, Habitat Area of Particular } \\
\text { Concern } \\
\text { For fish: no status }\end{array}$ & $\begin{array}{l}\text { For eelgrass: Essential Fish Habitat, } \\
\text { Habitat Area of Particular Concern, } \\
\text { Special Aquatic Site } \\
\text { For coastal wetlands: Special Aquatic } \\
\text { Site, US Waters } \\
\text { For shallow waters: US Waters }\end{array}$ & $\begin{array}{l}\text { For wetlands: Special Aquatic Site, US } \\
\text { Waters } \\
\text { For non-wetlands: US Waters }\end{array}$ \\
\hline & $\begin{array}{l}\text { Offset sizing } \\
\text { methodologies }\end{array}$ & $\begin{array}{l}\text { Methodology similar to Habitat } \\
\text { Equivalency Analysis (The Five-Step } \\
\text { Wetland Mitigation Ratio Calculator) }\end{array}$ & $\begin{array}{l}\text { For macroalgae: creation of a surface } \\
\text { area equivalent to lost kelp with four } \\
\text { absolute performance standards } \\
\text { including functioning and production } \\
\text { of fish biomass similar to a natural } \\
\text { reef } \\
\text { For fish: no standardized methodology } \\
\text { hypothesis that wetlands restoration } \\
\text { produces a value equal to or double }\end{array}$ & $\begin{array}{l}\text { For Inner and Outer Harbor mitigation } \\
\text { banks: ratios } \\
\text { For wetlands restoration projects: } \\
\text { modified Habitat Evaluation } \\
\text { Procedure and Habitat Equivalency } \\
\text { Analysis } \\
\text { For future out-of-kind projects: } \\
\text { Habitat Equivalency Analysis or The } \\
\text { Five-Step Wetland Mitigation Ratio }\end{array}$ & $\begin{array}{l}\text { California Rapid Assessment Method } \\
\text { or other appropriate functional } \\
\text { assessment methodology }\end{array}$ \\
\hline
\end{tabular}

${ }^{1}$ 'State Waters' refers to any surface water or groundwater, including saline waters, within the boundaries of the state of California. 


\begin{tabular}{|c|c|c|c|c|c|}
\hline & & & $\begin{array}{l}\text { that produced by an artificial reef on a } \\
\text { surface-area basis) }\end{array}$ & Calculator & \\
\hline & $\begin{array}{l}\text { Existing technical } \\
\text { solutions }\end{array}$ & $\begin{array}{l}\text { Feedback from transplantations over } \\
\text { the last } 25 \text { years in southern } \\
\text { California ( } 47 \text { projects) }\end{array}$ & $\begin{array}{l}\text { For macroalgae: solution based on } \\
\text { different types of experimental } \\
\text { designs } \\
\text { For fish: out-of-kind solution based on } \\
\text { wetland restoration feedback }\end{array}$ & $\begin{array}{l}\text { Feedback from wetland and eelgrass } \\
\text { restoration and artificial reef } \\
\text { programs developed in the 1960s in } \\
\text { California }\end{array}$ & $\begin{array}{l}\text { Feedback from wetland restoration in } \\
\text { southern California }\end{array}$ \\
\hline & $\begin{array}{l}\text { Temporal } \\
\text { dimension }\end{array}$ & $\begin{array}{l}\text { Feedback from transplantations over } \\
\text { the last } 25 \text { years }\end{array}$ & $\begin{array}{l}\text { Impact assessment before and during } \\
\text { the first two years of operation } \\
\text { Five-year monitoring of the } \\
\text { experimental phase of the artificial } \\
\text { reef }\end{array}$ & $\begin{array}{l}\text { No temporal dimension was identified } \\
\text { as key in the process. }\end{array}$ & $\begin{array}{l}\text { The SCWRP has existed since 1998, } \\
\text { providing the necessary hindsight on } \\
\text { priorities and knowledge about } \\
\text { wetland functioning }\end{array}$ \\
\hline & Spatial dimension & $\begin{array}{l}\text { First in southern California, then } \\
\text { throughout the state }\end{array}$ & $\begin{array}{l}\text { On a project scale (but includes out-of- } \\
\text { kind and off-site offset projects) }\end{array}$ & $\begin{array}{l}\text { At the port site (but includes out-of- } \\
\text { kind and off-site offset projects) }\end{array}$ & $\begin{array}{l}\text { In-lieu fee service area corresponds to } \\
\text { the SCWRP area, with three sub- } \\
\text { service areas based on watersheds, } \\
\text { hydrological networks, wetland types } \\
\text { and ecoregions }{ }^{2} \text {, geomorphological } \\
\text { provinces and economic viability } \\
\text { (sufficient offset demand) }\end{array}$ \\
\hline $\begin{array}{l}\text { Translation } \\
\text { elements }\end{array}$ & $\begin{array}{l}\text { Key element } \\
\text { enabling (or } \\
\text { blocking) the } \\
\text { interpretation of } \\
\text { the message }\end{array}$ & $\begin{array}{l}\text { Aligned objectives of the different } \\
\text { agencies } \\
\text { Explicit requirements within the } \\
\text { guidelines but also flexibility in order } \\
\text { to adapt to different technical } \\
\text { capacities of consultancies }\end{array}$ & $\begin{array}{l}\text { Creation of an independent committee } \\
\text { (MCR). Assessment of impacts and } \\
\text { offsets by independent scientists. }\end{array}$ & $\begin{array}{l}\text { USACE priorities different from those } \\
\text { of the other involved agencies }\end{array}$ & $\begin{array}{l}\text { Importance of the Interagency Revien } \\
\text { Team } \\
\text { Each agency is free to choose an in- } \\
\text { lieu fee program } \\
\text { Use of scientific and technical } \\
\text { resources established through the } \\
\text { SCWRP }\end{array}$ \\
\hline $\begin{array}{l}\text { Obligatory } \\
\text { passage points }\end{array}$ & $\begin{array}{l}\text { Developed } \\
\text { instrument }\end{array}$ & Recommended guidelines & $\begin{array}{l}\text { Offset solutions specific to the project, } \\
\text { including an experimental phase }\end{array}$ & $\begin{array}{l}\text { Umbrella Mitigation Banking } \\
\text { Agreement (UMBA) - abandoned }\end{array}$ & $\begin{array}{l}\text { In-lieu fee mitigation for wetlands } \\
\text { restoration }\end{array}$ \\
\hline & Requirements & $\begin{array}{l}\text { Required in permits issued by USACE } \\
\text { and often in coastal development } \\
\text { permits issued by the Coastal } \\
\text { Commission }\end{array}$ & Included in the amended permit & None (as not implemented) & $\begin{array}{l}\text { Soft preference of regulators is to use } \\
\text { in-lieu fee mitigation as a second } \\
\text { choice; this choice is left to the } \\
\text { signatory agencies and made on a } \\
\text { case-by-case basis during the permit } \\
\text { application process }\end{array}$ \\
\hline & Future challenges & $\begin{array}{l}\text { Increase in monitoring or certification } \\
\text { of consultancies by NMFS. Policy may } \\
\text { rely on eelgrass mapping funded by } \\
\text { southern California. }\end{array}$ & Offset objectives not yet attained & $\begin{array}{l}\text { For future impacts, either a case-by- } \\
\text { case offset will be developed for } \\
\text { impacts other than on US Waters or } \\
\text { Essential Fish Habitats, or a new bank } \\
\text { may be created for impacts on US } \\
\text { Waters or Essential Fish Habitats } \\
\text { according to the appropriate } \\
\text { procedure }\end{array}$ & $\begin{array}{l}\text { Operational implementation of the in- } \\
\text { lieu fee mitigation program }\end{array}$ \\
\hline
\end{tabular}

${ }^{2} \mathrm{An}$ 'ecoregion' is a homogenous geographic zone in terms of geomorphology, geology, climate, soils, water resources, fauna and flora. 